\title{
Evaluation of Patient- and Family-Centered Care in a Paediatric Clinic in Turkey: a Qualitative Study
}

\section{Türkiye'deki Bir Çocuk Kliniğinde Çocuk ve Aile Merkezli Bakımın Değerlendirilmesi: Niteliksel Çalışma}

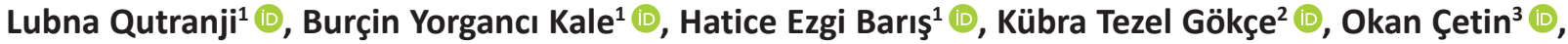 Esra Yılmaz ${ }^{3}$ (D) Emine Nural Öztürk ${ }^{3}$ (D) Perran Boran ${ }^{1}$ (D)}

\author{
${ }^{1}$ Marmara University, School of Medicine, Department of Paediatrics, Division of Social Pediatrics, Istanbul, Turkey \\ ${ }^{2}$ Marmara University, School of Medicine, Department of Pediatrics, Istanbul, Turkey \\ ${ }^{3}$ Marmara University, School of Medicine, Istanbul, Turkey
}

ORCID ID: L.Q. 0000-0001-8507-1278; B.Y.K. 0000-0002-0115-754X; H.E.B. 0000-0003-3396-8002; K.T.G. 0000-0002-9846-0544; O.Ç. 0000-0003-1672-4743; E.Y. 0000-0002-7488-2558; E.N.Ö. 0000-0002-2313-3426; P.B. 0000-0002-9885-7656

Citation/Atnf: Qutranji L, Yorganci-Kale B, Baris HE, Tezel Gokce K, Cetin O, Yilmaz E, Ozturk E, Boran P. Evaluation of patient- and family-centered care in a paediatric clinic in Turkey: a qualitative study. Çocuk Dergisi - Journal of Child 2021;21(3):231-236. https://doi.org/10.26650/jchild.2021.1000170

ABSTRACT

Objective: Patient- and family-centered care (PFCC) involves the engagement of both the patients and their families, considering them as an essential member of the healthcare team. The aim of this study was to evaluate PFCC experience of hospitalized children's parents in our hospital, assess current areas of strength and identify areas for growth for future improvement.

Material and Methods: The inclusion criteria for the study were parents of children who were hospitalized for at least three consecutive days. The data of 27 mothers, who were the child's primary caregiver in the hospital, were collected through face-to-face interviews. Children using immunosuppressive treatment were excluded from the study. Interviews lasted between 20 and 30 minutes. Data were analyzed using thematic framework analysis.

Results: Mothers reported both positive and negative experiences during their hospitalization period. One of the main findings of our current study was that Turkish parents usually do not prefer to take an active role during the decision-making process. However, they do expect to be fully informed about the disease, diagnostic procedures, treatment, and expected complications.

Conclusion: It is important to emphasize the importance of comprehensive implementation of PFCC for better healthcare outcomes. Recommendation includes offering communication skills training and education to healthcare providers and starting initiatives to improve the hospitals' environment.

Keywords: Family, Child, Patient Care, Decision Making, Health Personnel, Qualitative Research
ÖZ

Amaç: Hasta ve aile merkezli bakım hizmeti hem hastaların hem de bakım veren ebeveynlerin sağlık ekibinin önemli bir parçası olarak kabul edilmesini içerir. Bu çalışmanın amacı, hastanemizde yatan çocukların ebeveynlerinin hasta ve aile merkezli bakım hizmetleriyle ilişkili deneyimlerini değerlendirmek, olumlu kısımları saptamak ve geliştirilme intiyacı olan alanları belirlemektir.

Gereç ve Yöntemler: En az üç gün hastanede yatışı olan çocukların ebeveynleri çalışmaya dahil edilmiştir. Annelerin çocuklarının öncelikli bakım verenleri olması nedeniyle 27 çocuğun anneleri ile yüz yüze görüşme metodu kullanılarak veriler elde edilmiştir. İmmunsupresif kullanan çocuklar çalışma dışında bırakılmıştır. Görüşmeler oratalama 20-30 dakika sürmüştür. Görüşme çıktıları analiz edilip, tema rehberi belirlenmiştir. Bulgular: Anneler tarafında yatışları süresince olumlu ve olumsuz deneyimler bildirilmiştir. Ana bulgulardan biri; ülkemizdeki ebeveynlerin karar verme sürecinde aktif rol almayı tercih etmemesidir. Bununla birlikte ebeveynler mevcut hastalık, tanı, tedavi prosedürleri ve olası komplikasyonlarla ilgili bilgilendirilmek istedikleri belirtilmiştir.

Sonuç: Daha iyi sağıı sonuçları elde edebilmek adına hasta ve aile merkezli bakım hizmetlerinin etkin bir şekilde uygulanması çok önemlidir. Sağlık çalışanlarına iletişim becerileri konusunda eğitim vermek ve hastane ortamını iyileştirmeye yönelik girişimlerde bulunulması önerilmektedir.

Anahtar Kelimeler: Aile, Çocuk, Hasta bakımı, Karar verme, Sağlık çalışanları, Niteliksel araştırma

Corresponding Author/Sorumlu Yazar: Lubna Qutranji E-mail: lubna996@hotmail.com

Submitted/Başvuru: 27.09.2021 • Revision Requested/Revizyon Talebi: 07.10.2021 • Last Revision Received/Son Revizyon: 08.10.2021 • Accepted/Kabul: 12.10.2021 


\section{INTRODUCTION}

Patient- and family-centered care (PFCC) involves the engagement of both the patients and their families, considering them as an essential member of the healthcare team (1). In pediatric health care delivery, PFCC is thought to be the ideal care aimed to be reached by hospitals and healthcare professionals (2). It has been found to decrease children's length of stay in hospital and readmission rates (3). Moreover, it has been reported to increase parental satisfaction, decrease parental anxiety, and is linked to more positive clinical outcomes $(4,5)$. Yet, overemphasis on medical conditions undermines the importance of the social pediatrics approach in tertiary care centers, where partnership may be especially valuable in disease management.

All children have rights to the essential requirements for healthy growth and development for an optimal life. A nurturing care framework has been built on children's rights and has been proposed to ensure that children reach their developmental potential $(6,7)$. The framework specifically outlines the importance of access to medical care for health promotion. However, inequities related to unequal opportunities may interfere with health promotion. PFCC has been shown to mitigate the inequities resulting from social disparities in health care coordination (8). Therefore, pediatricians should recognize the importance of PFCC in promoting the health and well-being of children.

There is limited literature available about the family-centered care practices in Turkey. Numerous studies reported negative parental experiences. Parents did not have an active role in the decision-making process and many of them were not informed appropriately about their children's illness or course of the disease $(9,10)$. These findings highlight the importance of social pediatricians who aim to empower parents by guiding them to acquire knowledge of their child's health condition, understand their role in promoting their own children's health, and become active participants in their children's care.

In our study, we aimed to evaluate the PFCC experience of parents of hospitalized children in our hospital and assess current areas of strength and identify areas for growth for future improvement.

\section{MATERIAL AND METHODS}

\section{Participants and Setting}

The participants were recruited from the Pediatric ward of Marmara University Teaching and Research Hospital, a tertiary care hospital in Istanbul, Turkey, between January and March 2020.

Parents of children who were hospitalized for at least three consecutive days were included. Parents whose children were under immunosuppressive treatment were excluded because of increased risk of infection. The participants were purposively selected based on their age and reason for hospitalization to allow maximum variation in the sample. The interviews were conducted with more parents until a saturation point was reached, so that no further new themes emerged.

\section{Data collection}

The data of twenty-seven mothers were collected through face-to-face interviews. Mothers were chosen as they were the child's primary caregiver in the hospital. Children older than 3 years old were asked to fill in a poster with their wishes and priorities during their hospitalization period. A verbal explanation of the study was given to all the participants. Those who gave consent were interviewed. An interview topic guide was developed according to the general literature review, National Center for Family-Centered Care, and the policy statement published by the American Academy of Pediatrics $(1,11)$. The topic guide was pilot tested with five mothers and revised based on the feedback received. In-depth interviews aimed to explore 1) the core principles of PFCC, 2) participants' opinions on the children's clinic ward, and 3) children's wishes and needs during their hospitalization period.

Participants were interviewed in private rooms to maintain confidentiality. All the interviews lasted between 20 and 30 minutes and were audio-recorded.

\section{Data analysis}

Audio recordings were transcribed and analyzed in Turkish. Personal identifying data were removed, and data were analyzed using thematic framework analysis. To improve the rigor of the data analysis, each transcript was analyzed by two researchers. Similar codes were grouped to form the themes. The process of development of the thematic framework was supervised by the senior researcher (PB) and any discrepancies were discussed with the research team to clarify the findings.

\section{RESULTS / FINDINGS}

\section{Sociodemographic characteristics}

The sociodemographic characteristics are presented in Table 1. The age distribution of participants ranged from 23 to 50 years (median 34 years). The number of hospitalization days ranged from 3 to 75 days (median 6 days).

2. Core principles of patient- and family-centered care

\subsection{Decision-making team}

It was notable that most parents were only passively participating in the decision-making process, leaving the treatment choice and disease management to the health care providers.

- We do not interfere (with decision making), we respect healthcare providers (doctors) in that regard; I think they will not do anything unless it is necessary. (37-year-old single woman, mother of two children, university graduate, nurse)

\subsection{Respect and attentive listening}

Even though most parents were not actively participating in the decision-making process they seek detailed, trustful, and 
Table 1: General sociodemographic characteristics of participants

\begin{tabular}{ll}
\hline $\begin{array}{l}\text { Mother's age, median (IQR), years } \\
\text { Duration of hospitalization, median (IQR), days }\end{array}$ & $34(23-50)$ \\
$\begin{array}{ll}\text { Mother's education } \\
\quad \text { Illiterate, } \mathrm{n}(\%)\end{array}$ & $6(22.2)$ \\
$\quad$ Primary school, $\mathrm{n}(\%)$ & $8(29.6)$ \\
$\quad$ Middle school, $\mathrm{n}(\%)$ & $7(26)$ \\
$\quad$ High school, $\mathrm{n}(\%)$ & $5(18.5)$ \\
$\quad$ University, $\mathrm{n}(\%)$ & $1(3.7)$ \\
Employment Status & \\
$\quad \begin{array}{l}\text { Enemployed/Stay-at-home parent, } \mathrm{n}(\%) \\
\quad \text { Employed, } \mathrm{n}(\%)\end{array}$ & $25(92.5)$ \\
Consanguineous marriage, $\mathrm{n}$ (\%) & $2(7.5)$ \\
Number of children per family, median (IQR) & $4(14.8)$ \\
Children's age, median (IQR), years & $2(1-4)$ \\
Children age group, $\mathrm{n}$ (\%) & $4.5(0-16)$ \\
$\quad<12$ months & \\
$\quad \geq 12$ months & $10(37)$ \\
Number of individuals per house, median (IQR) & $4(3-7)$ \\
Income per family in USD, median (IQR) & $475(235-595)$ \\
\hline
\end{tabular}

consistent information about the disease, test results and treatment options.

- There is not enough information about the interventions. I went several times to know the results of blood tests; I was told on the third time. (25-year-old, married woman, mother of two children, middle-school graduate, stay-athome parent)

- I know it is not possible to talk to everyone individually, but at least when we ask a question, it's enough for them to say, "I am busy now, can you wait for just a second?" instead of "OK, wait!". (23-year-old, married woman, mother of two children, high-school graduate, stay-at-home parent)

Parents also commented on the communication skills of the health care personnel. It was interesting that some parents preferred a closer relationship with their healthcare provider instead of a more formal relationship.

- I feel that doctor K. feels as upset as I am when I talked to her. She understands me. (20-year-old, married woman, mother of one child, primary-school graduate, stay-at-home parent)

- There is a doctor who talks very casually with me; I loved her very much. (21-year-old, married woman, mother of one child, primary-school graduate, stay-at-home parent)

\subsection{Flexibility}

Some mothers complained of the complexity of the appointment system and its lack of flexibility.

- We had an appointment (in this hospital) about a week ago, but my child was hospitalized in another hospital at the same time. So, I missed the appointment given here. Even though I called the hospital to ask if it was possible to change my appointment to after 10 days or 1 month or even 2 months; it could not be done. (34-year-old, married woman, mother of two children, primary-school graduate, stay-at-home parent)

\subsection{Information sharing}

Getting a comprehensive explanation about their children's illness was the most emphasized point made by parents. They needed a detailed description of the disease including likely causes, pathophysiology, and complications.

- I would like to know how I should be followed up regarding his disease. I don't know if this is a permanent condition, I am wondering if she will have any complications. (42-yearold, married woman, mother of two children, primary-school graduate, stay-at-home parent)

- They changed the medications, but they didn't inform me of the change. (28-year-old, married woman, mother of four children, no school history, stay-at-home parent)

Some parents also criticized the use of medical jargon in the family-provider communication.

- They use big medical words which we don't understand. (25-year-old, married woman, mother of two children, middle-school graduate, stay-at-home parent)

On the other hand, explanation and using simpler terms were appreciated by patients.

- I should be able to get answers to my questions easily. For example, I have seen the word "Pneumonia". When I asked if you could explain it to me in a way that is understandable, they explained it to me as an infection. (21-year-old, married woman, mother of one child, primary-school graduate, stayat-home parent)

A couple of mothers expressed that the bedside visits should be more informative for the family, and not just discussion among themselves.

- They talk about the test results during the visits between themselves, mostly without telling us the results. They are already talking about the results, and they can also share the results with us during the visits. (25-year-old, married woman, mother of two children, middle-school graduate, stay-at-home parent)

\subsection{Supporting the family as the constant in the child's life}

A mother emphasized that she would like to be listened to and taken seriously when she shares her observations about her child's illness.

- I'm telling them that the noise is aggravating her seizures, but they did not take it seriously. (34-year-old, married woman, mother of three children, no school history, stayat-home parent) 


\subsection{Collaboration and involving children}

It was noted that most parents realized how busy the healthcare providers were, but still they expect that children are appropriately informed or prepared for medical testing and procedures.

- I understand that the nurses are too busy, but they are rushing us when placing intravenous catheters without leaving us time to prepare my child for the procedure. (28-year-old married woman, mother of two children, highschool graduate, stay-at-home parent)

Most parents mentioned that healthcare providers should also communicate with the child.

- Doctors should also talk to the child, ask her/him questions, and listen to the child. (34-year-old, married woman, mother of two children, primary-school graduate, stay-athome parent)

However, some parents were against sharing detailed information with their children.

- For example, they say that she has cancer next to her (the child). I don't think it is true. The child feels bad when the doctor talks about what the disease can do to her. (49-yearold, married woman, mother of two children, middle-school graduate, stay-at-home parent)

\section{Inpatient ward environment}

Overall, parents expressed that the clinic wards should be more child oriented, such as paintings on the wall or playrooms, even though there were some paintings on the walls.

- Corridors should be more colorful. There should be more picture books for little children in the library and children's channels on TV. Moreover, there should be wallpapers, closets, and curtains suitable for children. (37-year-old single woman, mother of two children, university graduate, nurse)

- The kitchen is on the other side of the corridor. I can't leave my baby alone and go there. I had to wash my baby's milk bottles in the bathroom sink. (25-year-old single woman, mother of two children, middle-school graduate, stay-athome parent)

One of the mothers mentioned the need for peer-to-peer support.

- My child gets bored. There must be activities for the children. Children need friends. (49-year-old, married woman, mother of two children, middle-school graduate, stay-at-home parent)

\subsection{Children's views and needs}

Children were asked to fill in a poster with the three most important things that matter to them or they want during their hospitalization period. However, due to age differences and different hospitalization reasons, not all children were able to participate. (See supplementary file 1 for a compilation of collected posters)

Most children wanted a designated playroom and tastier food.

- I want to eat kebab (6 years old, girl)

- I want cakes and sweets (4 years old, girl)

- I want a place full of activities for children (15 years old, girl)

One of the children wanted the internet and added three stars next to it to emphasize how much he needs it.

- Internet (9 years old, boy)

\section{DISCUSSION}

This study showed that Turkish parents usually do not prefer to take an active role during decision making processes. However, they do expect to be fully informed about the disease, diagnostic procedures, treatment, and expected complications. Furthermore, most pediatric healthcare professionals fail to apply the principles of PFCC during their everyday practices.

Parents were mostly passive in the decision-making process. It was noted that they usually see their involvement as interference with the healthcare provider's work. One possible reason may be low health literacy. Health literacy has been found to be correlated with one's willingness to participate in decision making (12). Another study suggested that relatives of patients in critical conditions were more likely to be anxious and depressed and as a result prefer not to be involved in decision making (13). On the other hand, shared decisionmaking is largely influenced by the physician's communication skills. The use of partnering and facilitative communication, such as asking directly for the parents' opinions encourages parents to express their concerns $(14,15)$.

In our study, most parents felt that healthcare providers did not take their observations into consideration. Similarly, numerous studies reported that the majority of parents were dissatisfied with both the quality and quantity of time spent with their healthcare providers $(9,10,16,17)$. Families should be acknowledged as the constant in a child's life, so their observations should be respected.

Another crucial component of PFCC is adequate information sharing. This includes giving detailed information about the child's illness in easy-to-understand language free of medical jargon (18). Bedside, rounds are an opportunity for information sharing. In our study, even though bedside rounds involved the presence of a parent, it did not involve their direct participation with the child's care. Parents observed that the medical team would discuss the child's laboratory results only among themselves. Introduction of family centered multidisciplinary rounds (FCMR), which is a component of PFCC, in the form of teaching session directed at residents and medical students is crucial $(19,20)$. 
Sharing honest and unbiased information with the parents and children has been defined as a component of PFCC. In our study, parents expected healthcare providers to inform their children about their illness, but this involved 'simple' diseases only. Parents preferred to shield their children from diseases with poor prognosis. This might be related to cultural reasons. A qualitative study in Iran reported that nurses would have to intentionally conceal the diagnosis in front of the hospitalized child to comply with the parents' wishes (21). Reports indicate that healthcare providers fail to involve children in health care decisions and information sharing which is a violation of a child rights regarding rights to obtain information, giving own opinions and expressing concerns (22). Pediatric healthcare providers should be trained about respecting children's rights when delivering healthcare and about the importance of sharing information with children in an age-appropriate manner.

We also found that parents appreciated when doctors supported them emotionally and preferred casual conversations. Emotional support and responsiveness were found to be effective in building rapport with the healthcare providers and in decreasing anxiety in patients $(21,23)$. This again emphasizes the importance of giving the family a safe space to express their feeling toward their child's illness. In order to ensure that healthcare providers can provide psychosocial support to parents, it is important to deliver appropriate education to staff to prevent burnout, compassion fatigue, and secondary traumatic stress syndrome (24).

Providing both formal and informal support is one of the key aspects of PFCC. Healthcare providers should screen for the families' wellbeing and need for support. This was rarely seen among our population and healthcare providers tended to focus more of their attention on the medical side of the illness. Social determinants of health play a vital role in health promotion and societal protection of the children and families from adverse outcomes and inequities (7). Healthcare providers should be aware of the available community services to refer the parents in case of emotional or social problems as they adversely affect the health and emotional or social well-being of their child (25).

Another important principle of PFCC is ensuring flexibility in organizational policies and procedures. Healthcare providers in tertiary care centers may specifically focus on the medical aspect of the diseases and treatment while social pediatricians who have the training for the skills and knowledge required to deliver PFCC may be the team leader to coordinate healthcare for the patients.

In our study, parents mentioned the need for informal support in terms of family-to-family and peer support. Social activities such as medical students visiting hospitalized children and spending time with them can be organized. Other efforts to ensure that families meet other families with children suffering similar healthcare conditions and providing opportunities for them to form support groups should be coordinated. Support groups provide a safe zone for parents to share their feelings.
It acts as a platform for them to ask questions freely and feel confident in becoming advocates for their children (26-29).

Regarding the ward environment, parents suggested child friendly paintings, furniture, and playrooms. Current evidence shows that the display of visual art has a positive effect on health outcomes including decreased levels of anxiety. This was shown to be particularly important for children staying in shared rooms, which is the case in our hospital (30). A study in an oncologic center showed higher parental satisfaction rate after redecorating the hospital ward to be more child oriented (31). Furthermore, kitchen location within the ward seemed to be problematic. Involving parents during ward design can direct interior designers into a more accessible design. Additionally, posters can be hung up in each room showing instructions on how to connect to the hospital's Wi-Fi.

Our study has several limitations. Firstly, our findings are not generalizable. Participants of different socioeconomical statuses or hospitalization in a private healthcare facility may lead to different views and opinions. Secondly, even though purposive sampling was used to achieve maximum variation, data was collected based on acceptance, which may limit the diversity of the data. However, interviews were conducted till maximum saturation was reached, to overcome this limitation. Finally, data were collected, while the child was still in the hospital, which may interfere with the parents' opinions. Even though all parents were assured about the confidentiality of data sampling, some parents may not have shared their negative opinions about their healthcare providers, worrying about being mistreated.

\section{CONCLUSION}

Overall, the findings of our study showed both strengths and weaknesses in our hospital's implementation of PFCC. Primary areas to improve on were patient doctor communication and shared decision making. Recommendation includes offering communication skills training and education to healthcare providers and starting initiatives to improve the hospital's environment. Social pediatricians should play an active role to ensure application of PFCC practices in tertiary care centers, particularly by taking a role in care coordination, ensuring care respecting child rights, recognizing families' needs and prompting community services to mitigate the effects of inequities.

Informed Consent: Written consent was obtained from the participants.

Peer Review: Externally peer-reviewed.

Author Contributions: Conception/Design of Study- L.Q., B.Y.K., H.E.B., K.G.T., P.B.; Data Acquisition- L.Q., B.Y.K., H.E.B., K.G.T., O.C., E.Y., E.O.; Data Analysis/Interpretation- L.Q., B.Y.K., H.E.B., P.B.; Drafting Manuscript- L.Q., B.Y.K., H.E.B., P.B.; Critical Revision of ManuscriptL.Q., B.Y.K., H.E.B., K.G.T., O.C., E.Y., E.O., P.B.; Final Approval and Accountability- L.Q., B.Y.K., H.E.B., K.G.T., O.C., E.Y., E.O., P.B.

Conflict of Interest: Authors declared no conflict of interest.

Financial Disclosure: Authors declared no financial support. 
Bilgilendirilmiş Onam: Katılımcılardan bilgilendirilmiş onam alınmıştır.

Hakem Değerlendirmesi: Dış bağımsız.

Yazar Katkıları: Çalışma Konsepti/Tasarım- L.Q., B.Y.K., H.E.B., K.G.T., P.B.; Veri Toplama- L.Q., B.Y.K., H.E.B., K.G.T., O.C., E.Y., E.O.; Veri Analizi/ Yorumlama- L.Q., B.Y.K., H.E.B., P.B.; Yazı Taslağı- L.Q., B.Y.K., H.E.B., P.B.; İçeriğin Eleştirel İncelemesi- L.Q., B.Y.K., H.E.B., K.G.T., O.C., E.Y., E.O., P.B.; Son Onay ve Sorumluluk- L.Q., B.Y.K., H.E.B., K.G.T., O.C., E.Y., E.O., P.B.

Çıkar Çatışması: Yazarlar çıkar çatı̧̧ması beyan etmemişlerdir.

Finansal Destek: Yazarlar finansal destek beyan etmemişlerdir.

\section{REFERENCES}

1. Committee on hospital care and institute for patient- and family-centered care. Patient- and family-centered care and the pediatricians role. Pediatrics 2012;129:394-404.

2. Mikkelsen G, Frederiksen K. Family-centred care of children in hospital - a concept analysis. J Adv Nurs 2011;67(5):1152-62.

3. Melnyk BM, Feinstein NF, Alpert-Gillis L, et al. Reducing premature infants' length of stay and improving parents' mental health outcomes with the Creating Opportunities for Parent Empowerment (COPE) neonatal intensive care unit program: a randomized, controlled trial. Pediatrics 2006;118(5):e1414-e1427.

4. De Bernardo G, Svelto M, Giordano M, Sordino D, Riccitelli M. Supporting parents in taking care of their infants admitted to a neonatal intensive care unit: a prospective cohort pilot study. Ital J Pediatr 2017;43(1):36.

5. Trzeciak S, Gaughan JP, Bosire J, Mazzarelli AJ. Association Between Medicare Summary Star Ratings for Patient Experience and Clinical Outcomes in US Hospitals. J Patient Exp 2016;3(1):6-9.

6. Pais MS, Bissell S. Overview and implementation of the UN Convention on the Rights of the Child. Lancet 2006;367(9511):68990.

7. Uchitel J, Alden E, Bhutta ZA, Goldhagen J, Narayan AP, Raman S, et al. The Rights of Children for Optimal Development and Nurturing Care. Pediatrics 2019;144(6):e20190487.

8. Toomey SL, Chien AT, Elliott MN, Ratner J, Schuster MA. Disparities in unmet need for care coordination: the national survey of children's health. Pediatrics 2013;131(2):217-24.

9. Tosun A, Güdücü Tüfekci F. Examination of family-centered care practices in pediatric clinics [Çocuk kliniklerinde aile merkezli bakim uygulamalarinin incelenmesi.] Journal of Anatolia Nursing and Health Sciences 2015;18(2).

10. Oktay H. Examining the care given in the pediatric wards of a university hospital in terms of family-centered care and determining the views of the mothers. [Bir üniversite hastanesinin çocuk servislerinde verilen bakımın aile merkezli bakım yönünden incelenmesi ve anne görüşlerinin belirlenmesi.] Hacettepe University Faculty of Health Sciences Nursing Journal 2009;16(1):11-24.

11. National Center for Family-Centered Care. Family-Centered Care for Children with Special Health Care Needs. (1989). Bethesda, MD: Association for the Care of Children's Health.

12. Brabers AE, Rademakers JJ, Groenewegen PP, van Dijk L, de Jong JD. What role does health literacy play in patients' involvement in medical decision-making? PLoS One 2017;12(3):e0173316.
13. Anderson WG, Arnold RM, Angus DC, Bryce CL. Passive decisionmaking preference is associated with anxiety and depression in relatives of patients in the intensive care unit. J Crit Care 2009;24(2):249-54.

14. Zandbelt LC, Smets EM, Oort FJ, Godfried MH, de Haes HC. Patient participation in the medical specialist encounter: does physicians' patient-centered communication matter? Patient Educ Couns 2007;65:396-406.

15. Street RL Jr, Gordon HS, Ward MM, Krupat E, Kravitz RL. Patient participation in medical consultations: why some patients are more involved than others. Med Care 2005;43:960-9.

16. Ammentorp J, Rasmussen AM, Nørgaard B, Kirketerp E, Kofoed $P E$. Electronic questionnaires for measuring parent satisfaction and as a basis for quality improvement. Int J Qual Health Care 2007;19(2):120-4.

17. Abuqamar M, Arabiat DH, Holmes S. Parents' Perceived Satisfaction of Care, Communication and Environment of the Pediatric Intensive Care Units at a Tertiary Children's Hospital. J Pediatr Nurs 2016;31(3):e177-e184.

18. Ong LM, de Haes JC, Hoos AM, Lammes FB. Doctor-patient communication: a review of the literature. Soc Sci Med 1995;40(7):903-18.

19. Mittal V. Family-centered rounds. Pediatr Clin North Am 2014;61(4):663-70.

20. Muething SE, Kotagal UR, Schoettker PJ, Gonzalez del Rey J, DeWitt TG. Family-centered bedside rounds: a new approach to patient care and teaching. Pediatrics 2007;119(4):829-32.

21. Shali M, Joolaee S, Navab E, Esmaeili M, Nikbakht Nasrabadi A. White lies in pediatric care: a qualitative study from nurses' perspective. J Med Ethics Hist Med 2020;13:16.

22. Ehrich J, Pettoello-Mantovani M, Lenton S, Damm L, Goldhagen J. Participation of children and young people in their health care: understanding the potential and limitations. J Pediatr 2015;167(3):783-4.

23. Wigert H, Dellenmark MB, Bry K. Strengths and weaknesses of parent-staff communication in the NICU: a survey assessment. BMC Pediatr 2013;13:71.

24. Mok E, Leung SF. Nurses as providers of support for mothers of premature infants. J Clin Nurs 2006;15(6):726-34.

25. Hall SL, Cross J, Selix NW, et al. Recommendations for enhancing psychosocial support of NICU parents through staff education and support. J Perinatol 2015;35(Suppl 1):S29-S36.

26. Pettoello-Mantovani M, Campanozzi A, Maiuri L, Giardino I. Familyoriented and family-centered care in pediatrics. Ital J Pediatr 2009;35(1):12.

27. Hall SL, Ryan DJ, Beatty J, Grubbs L. Recommendations for peer-topeer support for NICU parents. J Perinatol 2015;35(Suppl 1):S9-S13.

28. Bracht M, O'Leary L, Lee SK, O'Brien K. Implementing familyintegrated care in the NICU: a parent education and support program. Adv Neonatal Care 2013;13(2):115-26.

29. Ainbinder JG, Blanchard LW, Singer GH, et al. A qualitative study of Parent to Parent support for parents of children with special needs. Consortium to evaluate Parent to Parent. J Pediatr Psychol 1998;23(2):99-109.

30. Lankston L, Cusack P, Fremantle C, Isles C. Visual art in hospitals: case studies and review of the evidence. J R Soc Med 2010;103(12):490-9.

31. Hamdan A, Alshammary S, Tamani J, Peethambaran S, Hussein M, Alharbi M. The Impact of Creating A Child-Friendly Hospital Environment in Pediatric Cancer Patients and Their Families in Comprehensive Cancer Center at King Fahad Medical City. Curr Pediatr Res 2016;20:47-54. 